\section{EDUCATION AND THE COMMUNITY IN AFRICA}

\author{
By Prof. DARYLL FORDE \\ Director, International African Institute
}

$\mathrm{T}$ HE discrepancy between technological advance and social adaptation which is reflected in the crises and upheavals of the twentieth century is from many points of view the fundamental problem of our time. Although the economic and social problems of Africa may seem less urgent and menacing than those of Europe, this discordance and the social disequilibrium that accompanies it are, in fact, developing in an extreme form. The very fact that in Africa indigenous techniques and social organization have been comparatively simple means that the gap to be bridged in the process of integration with the Western world is correspondingly great and the social transformation all the more far-reaching. The pace of technological and economic change is quickening every day, and the need to smooth the path of the inevitable transition from small-scale tribal communities to a self-sustaining social organization commensurate with a large-scale exchange economy becomes increasingly urgent. There is perhaps little appreciation that failure may involve at a later stage violent social upheavals and zenophobia on a continental scale. Where the inadequacies of the existing agencies for social development and the evils of socially disintegrative individualism are seen at close quarters by the administrator, the missionary or the educator, the problems are often formulated only in economic or ethical terms and as questions of administrative machinery. The opportunities and needs for guiding the development of the more general social framework to meet the techniaal and economic changes have hitherto received little consideration. The fact that the effectiveness of such guidance will necessarily depend on the amounts of human energy and resources that are devoted to the reconstruction of the social organization of African communities finds inadequate recognition.

It is little more than a generation since the African villager lived in a small, practically elosed society in which status and obligations were determined by a network of local and personal relations. Farming and stock-raising required co-operation only with kinsmen and fellow villagers, Despite occasional and violent incursions from the vague outer world, religious and political concepts were, like economic values, bounded by a universe of a few thousand people. Even where centralized political institutions had created more considerable states, limitations on transport and division of labour left a high degree of autonomy to the local settlement group. The people in these small communities, knit together by a close web of inter-personal relations which guided and restrained their conduct at nearly every point, are all now being progressively affected by the rewards and demands of the world economy, and the regulations of an impersonal Western administration.

The old economic self-sufficiency of African communities is already a thing of the past. Even where direct production for local needs is still considerable, it is the new values associated with cash returns for crops and labour, market purchases of trade-goods, the achievement of new standards in dress and food and opportunities for learning new trades that are dominating the outlook of the energetic and pro- gressive. One of the most significant social aspects of this process is the fact that Africans have so often been brought into the orbit of the outer world not as communities but as individuals. The migrant or permanently urbanized wage-labourer, the villager whe sells his crop of maize, ground-nuts or palm oil for the external market, the hawker of cloth and hardware in village markets, and the middleman who buys up produce for the Western firms, all encounter and adapt themselves to the new economic opportunities and Western cultural values as individuals. There is at once a greater freedom for personal initiative in new fields and a weakening of effective control and support of the individual by the community. As the individual secures personal returns in an open market as well as a higher mobility and a widening choice of where and how to live, the old norms begin to lose their validity and the community itself to disintegrate. But new standards and a new social framework are slow to emerge. There is instead a trend towards detribalization into amorphous aggregations shot through with new forms of individual competitiveness-that are often restrained only by the external authority of the European administrative system. Unless the new occupations, rewards and demands are linked to social forms which can both ensure group benefits and security and harness individual effort to social ends, the period of adjustment from the old tribal life to a social equilibrium consistent with the new economies will be marred by social conflict, with waste of both human capacities and material resources.

The basic sociological principles underlying satisfactory adaptation to such rapid changes are not recondite. There is in the first place the need for attaching new functions and techniques to existing social structures, which are themselves concurrently adapted so that they do not become functionless and obstructive. By this means, the activities of the more capable and energetic who are in the vanguard of economic change do not become independent of the salutary restraints of group standards, with a significant loss of social solidarity.

Secondly, there is need for the progressive integration of the small-scale groups, appropriate to the earlier less complex economy, into larger and more comprehensive groups. Since the pattern of small groups, with their corporate sense and will to survive, already exists, economic change may easily lead to internecine struggles for dominance among them- struggles which result not only in loss of well-being and security by the unsuccessful but also in a less efficient, because economically less productive, transition to a new social pattern. The problem therefore resolves itself into securing progressively higher levels of group organization to which the loyalties and sense of interest attached to existing small groups is in part transferred. Intensification of faction within communities and jealous rivalry between them are typical social reactions to economic change where there is little grasp of the nature and long-term effects of the forces involved, and they can be reduced only by policies designed to promote understanding of the forces at work, and behaviour that is adjusted to new economic organization. This involves not merely education in the formal sense, but also the enlightening of the adult population and especially the leaders, traditional and newly arrived, concerning the technical and economic conditions of their lives.

These are among the main issues underlying the 
recent report on Mass Education in African Society by a Sub-Committee of the Advisory Committee on Education in the Colonies*, which rightly puts the active participation of the community in education proper and also in all projects for social development as the first requirement for satisfactory development under rapidly changing conditions. It comments acutely on a changing attitude towards economic disabilities or misfortunes, noting a growing attitude which tends to exaggerate the direct responsibility of groups or individuals, especially those in authority, for all such happenings. Both the suspicion of economic exploitation and the growth of political aspirations, as well as the often vague but far-reaching sense of participation in a common struggle during the War which confers common rights in the economic and political organization of the future, require constructive measures to avert narrowly nationalistic demands. The report recognizes that the need for combining effective guidance with the evocation of leadership from among the people themselves involves the co-ordination of many diverse agencies, which will, as is shown, prove no easy task. On one hand, members of the administration, education departments, technical services, missions and African churches must be welded into cooperating teams, subordinating their sectional or professional interests and prestige to the common objective of securing the greatest confidence and enlisting the fullest participation of the people themselves. For it is the widened experience and capacity for judgment which such participation can give that an educational programme should seek to provide. Only on such a basis will sustained effort and wise leadership be forthcoming from the African communities themselves. It presupposes, as the report points out, objectives with which the people can readily identify themselves, and while there must be provision for freedom of discussion and criticism, "there must be opportunity for extending the range of knowledge relevant to the changing conditions. Full discussion in itself is valuable, but it is not a substitute for being well informed".

The mass education programme is summed up as an effort to provide this experience and at the same time to "call out the ability and the will to share in the direction and control of the social, economic and political forces" by means of a co-ordinated effort of both official and unofficial agencies which will link up all development and welfare plans with community education, setting specific targets and attempting to imbue all groups and persons in the community with a sense of common effort and advantage. From some points of view the term 'mass education' as applied to such a programme is unfortunate. The objective is in fact the reverse of mass treatment. An articulate and appropriately differentiated community is the goal. The approach needs to be based in every case on the particular needs and opportunities in the given community and the activities of different persons and groups adjusted to their special functions, actual or potential. While the rapid promotion of literacy is an important aim, it is properly regarded as but the means to general advancement. The measures envisaged would not herd masses of adults into classes merely for reading and writing. It is community education in the widest sense that is urged; and that term, rather than one which suggests undifferentiated

* Colonial Office: Advisory Committee on Education in the Colonjes. Mass Education in African Society. (Colonial No. 186.) Pp. 64. (London: H.M. Stationery Office, 1944.) 1s. net. handling by uniform means, better expresses both the aims and the methods to be employed.

In framing the programme for any community, 'sociological mapping', together with a definition of the major obstacles to social and especially economic progress, which could provide the focus of public interest for an educational campaign, are held to be prerequisite. It is also urged that every advantage should be taken of existing educational agencies, formal and informal, and every attempt made to enlist the co-operation of indigenous organizations. In this connexion the point might well have been made that the very process of associating diverse organizations in a comprehensive scheme should have considerable educational value in promoting an awareness of social forces and a capacity to consider social organization in terms of practical needs. Organizations, whether indigenous or implanted, from secret societies and age-sets to mission units and village councils, will tend to be judged according to the service they can render. The need for preliminary survey whereby those in charge can secure a sound grasp of the social structure of the community in question is repeatedly emphasized: "however good the content of a mass education plan and its technique may be, it cannot hope to be successful unless it is carried out by people who know their society and its significant sociological forms and how they are changing under modern conditions". An essential point in the suggested organization is the appointment of "Mass Education Officers" to co-ordinate and supervise the work in any one area. Although not recruited from any one source, they will need training, as well as flair and interest, for understanding and securing the co-operation of the community in each project, and then guiding the development to promote social cohesion and welfare.

This point is perhaps one which needs particular attention, since it is but one instance of a growing need for investigators and executants with sociological training, for which there is at present only the most meagre provision in British educational institutions. The notion that training is required for independent and empirical inquiry into social structures and the forces that sustain them, and even that such inquiries are pre-requisite for intelligent control of social development, has yet to make its way. The relevance of sociological theory and field methods to the practical problems of politics and social development finds little recognition. A sense of history, a sound ethical code and a fair mind, on which the British traditions of public administration and social reform insist, are no doubt admirable qualities, but they do not dispense with the need for methodological safeguards against misconceptions and unconscious prejudice, or for the application of scientific knowledge of social processes. Our engineers and medical men are expensively trained to acquire a body of tested principle, a capacity for diagnosis and the ability to apply their knowledge to particular problems. Sociological principles and methods are left to filter indirectly and belatedly into our educational system. In questions of social policy, standards of careful investigation and logical analysis are often lacking. The accelerated pace of social change in colonial dependencies, involving as it does many societies generically distinct in type, is focusing attention on this need in a field in which the social anthropologists have already pioneered; but sociological training and research will have to be further developed on a very considerable scale if recommendations such as those of this report are to be implemented. 